\title{
Asbestos Mining
}

National Cancer Institute

\section{Source}

National Cancer Institute. Asbestos Mining. NCI Thesaurus. Code C107390.

An occupation that involves the extraction of asbestos from naturally-occurring silicate deposits. Asbestos miners were shown to have an increased risk of developing asbestosis, bronchogenic carcinoma and malignant mesothelioma. 